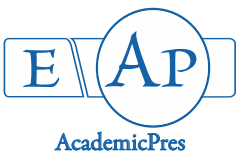

El-Gazzar A et al. (2020)

Notulae Scientia Biologicae 12(1):14-21

DOI: $10.15835 / \mathrm{nsb} 12110574$

Research Article

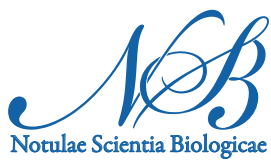

\title{
Two additions to the Asteraceae of Egypt
}

\section{Adel EL-GAZZAR ${ }^{1 *}$, Nahed EL-HUSSEINI ${ }^{2}$, Azza A.F. KHAFAGI ${ }^{3}$, Nashwa A.M. MOSTAFA ${ }^{1}$}

\author{
${ }^{I}$ El-Arish University, Faculty of Science, Department of Botany and Microbiology, El-Arish, N. Sinai, \\ Egypt; elgazzar_adel@hotmail.com (*corresponding author); bent_sina2009@yahoo.com \\ ${ }^{2}$ Cairo University, Faculty of Science, Department of Botany, The Herbarium, Giza, Egypt; nabedelhusseini@gmail.com \\ ${ }^{3}$ Al-Azhar University, Girls Branch, Faculty of Science, Department of Botany, Madinet Nasr, Cairo, Egypt; azzakhafagi@yahoo.com
}

\begin{abstract}
The novel occurrence of Helenium amarum (Raf.) H. Rock var. amarum and Pulicaria dysenterica (L.) Gaertn. (Asteraceae) in the flora of Egypt is reported. Apart from the single collection of H. amarum var. amarum in Australia, this taxon was not recorded previously outside its country of origin in South-Eastern United States and Mexico. With the recording of Pulicaria dysenterica in Egypt, Libya remains the only Mediterranean country where it has not as yet been found. Detailed description of the two species in terms of 83 characters is provided. A data matrix including the eight Pulicaria species found in Egypt and 19 of their morphological characters was compiled and a conventional key was constructed using the key-generating computer program suit DELTA.
\end{abstract}

Keywords: Asteraceae; DELTA; flora; Helenium amarum; key; Pulicaria dysenterica

\section{Introduction}

In the course of preparing a comprehensive data base of the Asteraceae in Egypt (El-Gazzar et al., 2019 a, b), we came across some specimens in the holdings of the herbarium of Cairo University (CAI) collected in widely separated localities in Egypt and representing two different taxa: a single specimen of Helenium amarum (Raf.) H. Rock var. amarum (kept as Helenium tenuifolium Nutt.) and three specimens of Pulicaria dysenterica (L.) Gaertn. Although the specimen of Helenium amarum (Raf.) H. Rock var. amarum was collected by M. Hassib in Sinai in April 1940, it was not until August 1972 when it was identified at Kew by C. Jeffrey. The three specimens of Pulicaria dysenterica (L.) Gaertn. were collected in different localities east of the Nile Delta during 1980 and 1981. The two taxa were overlooked in subsequent floras of Egypt (e.g. Täckholm, 1974; ElHadidi and Fayed, 1994/1995; Boulos and Hind, 2002) and in detailed floristic revisions of the family (Fayed and Mohamed, 1991; Zareh, 2005a and 2005b).

The data base established by us specifically for the Asteraceae of Egypt consists of two parts. The first part (El-Gazzar et al., 2019a) is devoted entirely to the spiny taxa and consists of 51 characters recorded for 65 species belonging to 20 genera. The second part (El-Gazzar et al., 2019b) is concerned solely with the more 
numerous spineless taxa of the family and encompasses 195 states of 83 characters recorded for each of 158 species from 77 genera.

The present article aims to add Helenium amarum (Raf.) H. Rock var. amarum and Pulicaria dysenterica (L.) Gaertn. to the spineless taxa representing the Asteraceae in the flora of Egypt and to provide detailed descriptions for them.

\section{Materials and Methods}

Collection data of the specimens located in the Cairo University Herbarium (CAI) and used in the present study as material evidence of the occurrence of two species of Asteraceae in the flora of Egypt are as follows:

Helenium amarum (Raf.) H. Rock var. amarum (kept as Helenium tenuifolium Nutt.): M. Hassib, s.n., April 1940, Sinai, mountain region, (CAI). [determined at Kew by C. Jeffrey on 8/8/1972] (Figure 1).

Pulicaria dysenterica (L.) Gaertn.: A. El Bakry 1776, 28/10/1980, El-Mullak, Cairo-Ismailia Region, East of the Nile Delta, (CAI); A. El Bakry 1868, 26/12/1980, El-Abbasa, Cairo-Ismailia Region, East of the Nile Delta, (CAI); A. El Bakry 3260, 2/10/1981, Inshas, Cairo-Ismailia Region, East of the Nile Delta, (CAI). [identified originally as Pulicaria dysenterica (L.) Bernh.] (Figure 2).

Identification of the two species was verified with the help of appropriate floras (e.g. Andrews, 1956; Feinbrun-Dothan, 1977, 1978; Barkley et al., 2006; Bierner, 2006), the monograph of Pulicaria by GamalEldin (1981) and the flora of China (Chen and Anderberg, 2018) for Pulicaria dysenterica. Nomenclature was updated according to the two websites of The Plant List (2016) and The Missouri Botanical Garden (2017).

In order to distinguish between the eight Pulicaria species in Egypt, a conventional key was generated using a set of 19 morphological characters recorded for each of them and the key-generating program DELTA (Dallwitz et al., 1993 onwards; Dallwitz and Paine, 2005).

\section{Results and Discussion}

The following are the detailed descriptions of the two species added for the first time to the Asteraceae of Egypt as extracted from the data base established by us (El-Gazzar et al., 2019b) for the spineless representatives of the family in the local flora.

1. Helenium amarum (Raf.) H. Rock var. amarum, Rhodora 59:131. (1957) (Figure 1).

Basionym: Gaillardia amara Raf., [as Galardia amara], Fl. Ludov., pp 69-70 (1817)

Syn. Helenium tenuifolium Nutt., Journal of the Academy of Natural Science Philadelphia, 7(1):66. (1834)

Plant herb. Plant erect. Plant green. Stem branched. Stem solid. Stem not winged. Stem not prickly. Stem globous. White bulbous hairs on stem absent. Apically forked simple hairs on stem absent. Glandular hairs on stem absent. Leaves cauline. Leaves filiform. Leaves alternate. Leaves sessile. Average leaf blade length in $\mathrm{cm}$ 4-11.5. Average leaf blade width in $\mathrm{cm} 1.7$ or less. Leaves simple. Leaf blade linear-lanceolate. Leaves without deltoid lobes. Base of blade clasping. Leaf base epulvinate. Leaf base not auriculate. Stipules absent. Leaf base symmetrical. Leaf apex acute. Horny nails on leaf apex or margin absent. Leaf margin entire. Leaf margin flat. Leaves without black or brown dots. Leaf main veins one. Leaf main veins not prominent. Leaves not white mottled. Leaf upper surface glabrous. Leaf lower surface glabrous. Glandular hairs on leaves absent. Lower surface of leaf midrib and margin not prickly. White bulbous hairs on leaf blade absent. Apically forked simple hairs on leaves absent. Capitula globose. Capitula terminal solitary or in clusters. Average length of capitulum in $\mathrm{cm} 1.7$ or less. Average width of capitulum in cm 1.2 or less. Receptacle conical. Phyllaries with two or more midribs. Phyllaries in one row. Phyllaries soft. Outer phyllaries linear-lanceolate. Outer phyllaries 
flat. Outer phyllaries herbaceous. Outer phyllaries completely united. Horny nails on outer phyllaries tips absent. Apex of outer phyllaries acute to acuminate. Phyllaries apex green. Black-dots on outer phyllaries absent. Outer phyllaries not gland-dotted. Outer phyllaries glabrous. White bulbous hairs on upper surface of outer phyllaries absent. Apically forked simple hairs on outer phyllaries absent. Prickles on surface of outer phyllaries absent. Marginal membrane of outer phyllaries absent. Inner phyllaries reduced. Marginal flower fully developed. Underground achenes absent. Position of corolla on achene straight. Achenes obconical-obovate. Achene apex spineless. Achene base symmetrical. Achene base not sagittate. Achene sessile. Glands on achene surface absent. Hooked appendages on achenes absent. Outer achenes not curved. Base of outer achenes not horned. Outer achenes without lateral wings. Surface of outer achene hairy. Outer achenes compressed. Outer achenes not beaked. Inner achenes not curved. Inner achenes without lateral wings. Surface of inner achenes hairy. Inner achenes compressed. Inner achenes not beaked. Pappus on all achenes.

2. Pulicaria dysenterica (L.) Gaertn., Fruct. Sem. Pl. 2:462. (1791) (Figure 2).

Basionym: Inula dysenterica L., Sp. Pl. 2: 882. (1753)

Syn.: Aster dysentericus (L.) Scop., Fl. Carniol. ed. 2, 2:171. (1772)

Pulicaria dysenterica (L.) Bernh., Syst. Verz. Pfl. Erfurt 153. (1800)

Diplopappus dysentericus (L.) Bluff. \& Fingerh., Comp. Fl. German. 2:309. (1825).

Pulicaria gracilis Heimerl, in Stapf, Denkschr. Akad. Wiss. Wien Math. Nat. Kl. 50(2):56. (1885).

Plant shrub. Plant erect. Plant green. Stem branched. Stem solid. Stem not winged. Stem not prickly. Stem sparsely hairy. White bulbous hairs on stem absent. Apically forked simple hairs on stem absent. Glandular hairs on stem absent. Leaves sessile. Leaves linear. Average leaf blade length in cm 0.5-3.5. Average leaf blade width in $\mathrm{cm} 1.7$ or less. Leaves simple. Leaf blade linear-lanceolate. Leaves without deltoid lobes. Base of blade clasping. Leaf base epulvinate. Leaf base not auriculate. Stipules present. Leaf base symmetrical. Leaf apex acute. Horny nails on leaf apex or margin absent. Leaf margin entire. Leaf margin flat. Leaves without black or brown dots. Leaf main veins not prominent. Leaves not white mottled. Leaf upper surface white tomentose. Leaf lower surface white tomentose. Glandular hairs on leaves present. Lower surface of leaf midrib and margin not prickly. White bulbous hairs on leaf blade absent. Apically forked simple hairs on leaves absent. Capitula not globose. Capitula in raceme or rarely circinnate. Average length of capitulum in $\mathrm{cm} 1.7$ or less. Average width of capitulum in $\mathrm{cm} 1.2$ or less. Receptacle not conical. Phyllaries with one midrib. Phyllaries in 2 or more rows. Phyllaries soft. Outer phyllaries linear-lanceolate. Outer phyllaries flat. Outer phyllaries herbaceous. Outer phyllaries free. Horny nails on outer phyllaries tips absent. Apex of outer phyllaries acute to acuminate. Phyllaries apex green. Black-dots on outer phyllaries absent. Outer phyllaries gland dotted. Outer phyllaries hirsute. White bulbous hairs on upper surface of outer phyllaries absent. Apically forked simple hairs on outer phyllaries absent. Prickles on surface of outer phyllaries absent. Marginal membrane of outer phyllaries entire. Inner phyllaries linear-lanceolate. Marginal flower fully developed. Underground achenes absent. Position of corolla on achene straight. Achenes elongate-fusiform. Achene apex spineless. Achene base symmetrical. Achene base not sagittate. Achene sessile. Glands on achene surface absent. Hooked appendages on achenes absent. Outer achenes not curved. Base of outer achenes not horned. Outer achenes without lateral wings. Surface of outer achene striate, or hairy. Outer achenes not compressed. Outer achenes not beaked. Inner achenes not curved. Inner achenes without lateral wings. Surface of inner achenes striate, or hairy. Inner achenes not compressed. Inner achenes not beaked. Pappus on all achenes. 
El-Gazzar A et al. (2020). Not Sci Biol 12(1):14-21.

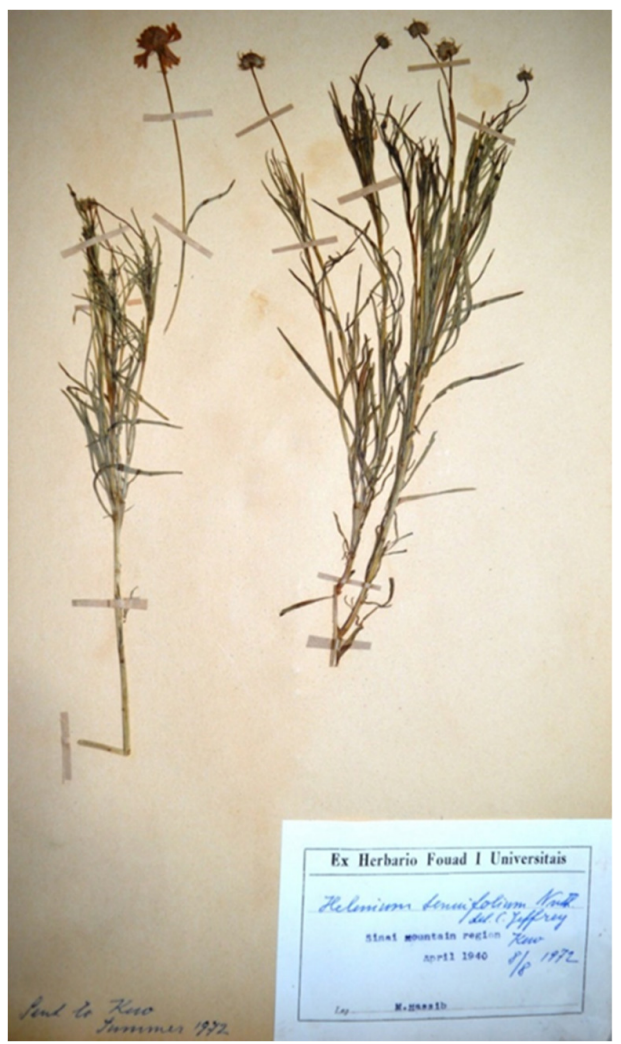

Figure 1. Image of the herbarium specimen of Helenium amarum var. amarum

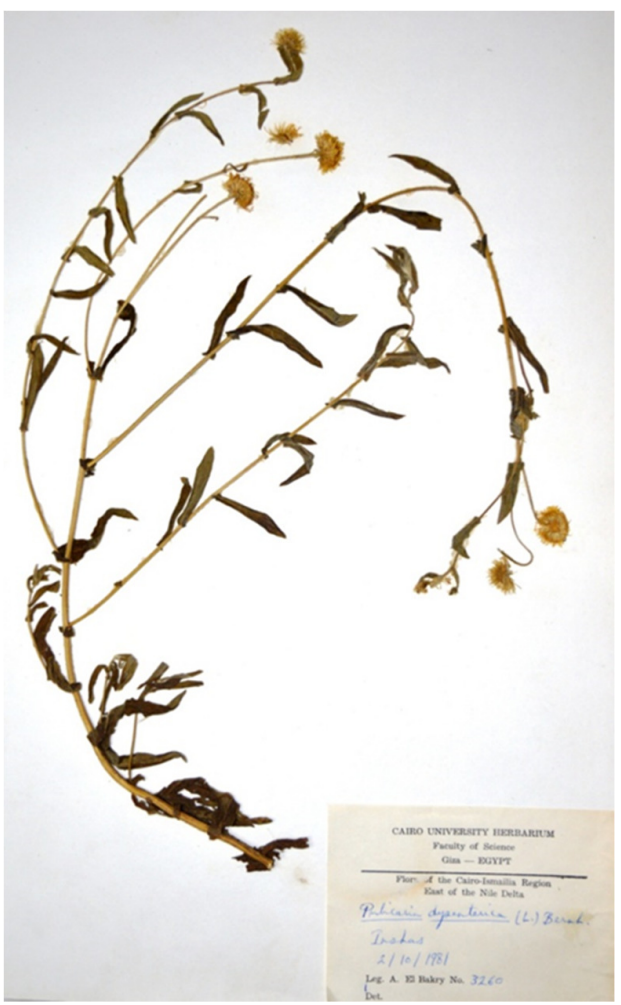

Figure 2. Image of one herbarium specimen of Pulicaria dysenterica 
The following is a computer-generated conventional key to the eight Pulicaria species based on 19 morphological characters; only 11 characters of the stem and leaves were used in key construction:

Characters: 19 in data, 19 included, 11 in key.

Items: 8 in data, 8 included, 8 in key.

Parameters: Rbase $=1.40$ Abase $=2.00$ Reuse $=1.01$ Varywt $=0.80$

Characters included: $1-19$

Character reliabilities: $1-19,5.0$

1.Leaf upper surface glabrous; leaf lower surface glabrous............................................................2

Leaf upper surface hairy; leaf lower surface hairy ..................................................................... 4

Leaf upper surface tomentose; leaf lower surface tomentose................... Pulicaria incisa (Lam.) DC.

2(1). Glandular hairs on stem present; leaves petiolate; leaves $4-11.5 \mathrm{~cm}$ long; leaves $2-9 \mathrm{~cm}$ broad. Pulicaria petiolaris - Jaub. et Spach

Glandular hairs on stem absent; leaves sessile; leaves $0.5-3.5 \mathrm{~cm}$ long; leaves $0.3-1.7 \mathrm{~cm}$ broad ............3

3(2). Leaf apex acute; plant shrub; stem glabrous; outer phyllaries gland-dotted ..Pulicaria sicula (L.) Moris

Leaf apex mucronate; plant herb; stem sparsely hairy; outer phyllaries not glanddotted.................................................................................................... Pulicaria undulata (L.) C.A.Mey.

4(1). Leaf apex acute . .5

Leaf apex mucronate .............................................................................Pulicaria arabica (L.) Cass.

Leaf apex rotund Pulicaria vulgaris Gaertn.

5(4). Leaf margin entire Pulicaria dysenterica (L.) Gaertn.

Leaf margin dentate-crenate Pulicaria inuloides (Poir.) DC.

Detailed descriptions of the eight species in terms of the 19 characters used in the process of key generation are as follows:

Pulicaria arabica (L.) Cass.

Plant shrub. Stem sparsely hairy. Glandular hairs on stem absent. Leaves sessile. Leaves $4-11.5 \mathrm{~cm}$ long. Leaves 0.3-1.7 cm broad. Leaf blade linear-lanceolate. Leaf apex mucronate. Leaf margin entire. Leaf margin flat. Leaf with one main vein. Leaf main veins not prominent. Leaf upper surface hairy. Leaf lower surface hairy. Glandular hairs on leaves present. Outer phyllaries gland-dotted. Outer phyllaries hirsute. Margin of outer phyllaries membranous. Leaf margin not undulate.

Pulicaria dysenterica (L.) Gaertn.

Plant shrub. Stem sparsely hairy. Glandular hairs on stem absent. Leaves sessile. Leaves 4-11.5 cm long. Leaves 0.3-1.7 cm broad. Leaf blade linear-lanceolate. Leaf apex acute. Leaf margin entire. Leaf margin revolute. Leaf with one main vein. Leaf main veins not prominent. Leaf upper surface hairy. Leaf lower surface hairy. Glandular hairs on leaves present. Outer phyllaries not gland-dotted. Outer phyllaries tomentose. Margin of outer phyllaries green. Leaf margin not undulate.

Pulicaria incisa (Lam.) DC.

Plant herb. Stem tomentose. Glandular hairs on stem absent. Leaves sessile. Leaves $0.5-3.5 \mathrm{~cm}$ long. Leaves 0.3-1.7 cm broad. Leaf blade oblong. Leaf apex acute. Leaf margin entire. Leaf margin flat. Leaf with one main vein. Leaf main veins not prominent. Leaf upper surface tomentose. Leaf lower surface tomentose. Glandular hairs on leaves present. Outer phyllaries not gland-dotted. Outer phyllaries tomentose. Margin of outer phyllaries green. Leaf margin undulate.

Pulicaria inuloides (Poir.) DC. 
Plant shrub. Stem sparsely hairy. Glandular hairs on stem absent. Leaves sessile. Leaves $4-11.5 \mathrm{~cm}$ long. Leaves $0.3-1.7 \mathrm{~cm}$ broad. Leaf blade linear-lanceolate. Leaf apex acute. Leaf margin dentate-crenate. Leaf margin revolute. Leaf with one main vein. Leaf main veins not prominent. Leaf upper surface hairy. Leaf lower surface hairy. Glandular hairs on leaves present. Outer phyllaries not gland-dotted. Outer phyllaries tomentose. Margin of outer phyllaries green. Leaf margin not undulate.

Pulicaria petiolaris Jaub. et Spach

Plant herb. Stem sparsely hairy. Glandular hairs on stem present. Leaves petiolate. Leaves $4-11.5 \mathrm{~cm}$ long. Leaves $2-9 \mathrm{~cm}$ broad. Leaf blade ovate. Leaf apex acute. Leaf margin dentate-crenate. Leaf margin flat. Leaf with with pinnate main veins. Leaf main veins prominent. Leaf upper surface glabrous. Leaf lower surface glabrous. Glandular hairs on leaves present. Outer phyllaries not gland-dotted. Outer phyllaries hirsute. Margin of outer phyllaries green. Leaf margin not undulate.

\section{Pulicaria sicula (L.) Moris}

Plant shrub. Stem glabrous. Glandular hairs on stem absent. Leaves sessile. Leaves $0.5-3.5 \mathrm{~cm}$ long. Leaves $0.3-1.7 \mathrm{~cm}$ broad. Leaf blade linear-lanceolate. Leaf apex acute. Leaf margin entire. Leaf margin flat. Leaf with one main vein. Leaf main veins not prominent. Leaf upper surface glabrous. Leaf lower surface glabrous. Glandular hairs on leaves absent. Outer phyllaries gland-dotted. Outer phyllaries glabrous. Margin of outer phyllaries membranous. Leaf margin not undulate.

Pulicaria undulata (L.) C.A.Mey.

Plant herb. Stem sparsely hairy. Glandular hairs on stem absent. Leaves sessile. Leaves $0.5-3.5 \mathrm{~cm}$ long. Leaves $0.3-1.7 \mathrm{~cm}$ broad. Leaf blade linear-lanceolate. Leaf apex mucronate. Leaf margin entire. Leaf margin flat. Leaf with one main vein. Leaf main veins not prominent. Leaf upper surface glabrous. Leaf lower surface glabrous. Glandular hairs on leaves absent. Outer phyllaries not gland-dotted. Outer phyllaries hirsute. Margin of outer phyllaries green. Leaf margin undulate.

Pulicaria vulgaris Gaertn.

Plant herb. Stem sparsely hairy. Glandular hairs on stem absent. Leaves sessile. Leaves $0.5-3.5 \mathrm{~cm}$ long. Leaves $0.3-1.7 \mathrm{~cm}$ broad. Leaf blade linear-lanceolate. Leaf apex rotund. Leaf margin entire. Leaf margin flat. Leaf with one main vein. Leaf main veins not prominent. Leaf upper surface hairy. Leaf lower surface hairy. Glandular hairs on leaves present. Outer phyllaries gland-dotted. Outer phyllaries hirsute. Margin of outer phyllaries membranous. Leaf margin undulate.

To distinguish between the two newly recorded taxa (Helenium amarum var. amarum and Pulicaria dysenterica) and the rest of genera and species representing the Asteraceae in the flora of Egypt, they have been incorporated into a computer-generated conventional key to the spineless taxa of this family (El-Gazzar et al., $2019 \mathrm{~b}$ ) based on 83 characters recorded for every taxon. With the addition of both taxa, the spineless Asteraceae are represented in Egypt by 160 species belonging to 78 genera.

The occurrence of Helenium amarum var. amarum in the mountainous area of southern Sinai is a new generic and specific record in the flora of Egypt. It also seems to be the only record of this taxon outside its country of origin in South-Eastern United States and Mexico and a single locality in Australia.

Helenium amarum (Raf.) H. Rock var. amarum is widespread in the south-eastern United States and California (USDA, 2018) and Mexico. The two specimens of this taxon cited by Bean (2015) indicate that they were collected in 1953 and 2007 from one location in Lowood District, Mount Tarampa aerodrome in the Lockyer Valley of Queensland, Australia, where it was reported to be poisonous to livestock and competes with pasture and native vegetation. This is so far the only record of this species and its variety outside the Americas. Bean (2015) also reported that Mount Tarampa aerodrome was used by the United States Air Force 
during World War II, which might explain the accidental introduction of this exclusively American species into Australia. Ecologically, H. amarum var. amarum prefers open fields, roadsides and disturbed areas in subhumid, warm temperate and subtropical areas in USA and Australia where annual rainfall is less than $1000 \mathrm{~mm}$ and the soil are calcareous, sandy, loam or clay loam (Anonymous, 2016). Such environmental conditions are closely similar to those prevailing in the valleys of the central and southern parts of the Sinai Peninsula, Egypt, where the only collection of the species was made. It is interesting to note that this locality is part of the passage of a continuous stream of religious tourism to St. Catherine Monastery in southern Sinai, which might have accidentally brought this taxon to this otherwise uninhabited spot.

\section{Conclusions}

Despite the continuous efforts of the amateur and professional botanists who studied the flora of Egypt for more than 250 years, this flora is so dynamic that new records can still be made. While the predominantly Mediterranean species Pulicaria dysenterica may be regarded as native, the almost exclusively American taxon Helenium amarum var. amarum is decidedly alien in Egypt.

\section{Acknowledgements}

This research received no specific grant from any funding agency in the public, commercial, or not-forprofit sectors.

\section{Conflict of Interests}

The authors declare that there are no conflicts of interest related to this article.

\section{References}

Abdalla EJM (2009). A taxonomic study on the genus Pulicaria in the Sudan. M.Sc. Thesis, University of Khartoum, pp 49.

Andrews FW (1956). The flowering plants of the Sudan. Compositae-Gramineae. T Buncle \& Co., Ltd., Abroath, Scotland. Vol. 3.

Anonymous (2016). Bitterweed. Queensland Government, Business Queensland.

Bean AR (2015). Helenium. In: Wilson A (Ed). Asteraceae 1, subfam. Asteroideae, tribe Helenieae. Flora of Australia $37: 445-446$.

Bierner MW (2006). Helenium amarum. In: Flora of North America North of Mexico. 21:428. www.efloras.org

Boulos L, Hind DJN (2002). Compositae. In: Boulos L (Ed). Flora of Egypt, vol. 3. Verbenaceae-Compositae. Al Hadara Publishing, Cairo, pp 134-317.

Chen Y, Anderberg AA (2018). Asteraceae. 12. Tribe Inuleae. Flora of China 20(21):827. www.efloras.org/florataxon.asp $x$ ?flora_id $=20541$

Dallwitz MJ, Paine TA (2005). Definition of the DELTA format. http://delta-intkey.com/standard.htm

Dallwitz MJ, Paine TA, Zurcher EJ (1993). User's guide to the DELTA system: a general system for processing taxonomic descriptions. 4th edition. http://delta-intkey.com

El-Gazzar A, El-Husseini N, Khafagi AA, Mostafa NAM (2019a). Computer-generated keys to the flora of Egypt. 8. The spiny taxa of Asteraceae. Egyptian Journal of Botany 59(1):209-232. 
El-Gazzar A, El-Husseini N, Khafagi AA, Mostafa NAM (2019b). Computer-generated keys to the flora of Egypt. 10. The spineless taxa of Asteraceae. Egyptian Journal of Botany 59(1).

El Hadidi MN, Fayed AA (1994/95). Materials for excursion flora of Egypt (EFE). Taeckholmia 15:1-233.

Fayed AA, Mohamed M (1991). Systematic revision of Compositae in Egypt. 5. Tribe Inuleae: Pulicaria and related genera. Willdenowia 20:81-89.

Feinbrun-Dothan N (1977). Flora of Palestine. Part 3-Plates. Ericaceae-Compositae. The Israel Academy of Science and Humanities, Jerusalem pp 490-757.

Feinbrun-Dothan N (1978). Flora Palestine. Part 3-Text. Ericaceae-Compositae. The Israel Academy of Science and Humanities, Jerusalem pp 285-447.

Gamal-Eldin E (1981). Revision der Gattung Pulicaria (Compositae-Inuleae) für Afrika, Makaronesien und Arabien. Phanerogamen Monographiae Tomus XIV. J. Cramer. Germany, Vaduz pp 311 pp.

Greuter W (2006+). Compositae (pro parte majore). In: Greuter W, Raab-Straube E von (Eds). Compositae. Euro+Med Plantbase - the information resource for Euro-Mediterranean plant diversity.

Simpson A, Eyler MC, Cannister M, Libby R, Rozlowski N, Sellers E, Guala, GF (2018). Dataset of the first comprehensive list of the non-native species established in three major regions of the United States. U.S. Geological Survey Data Release. https://doi.org/10.5066/P9E5K160

Täckholm V (1974). Students' flora of Egypt (2nd ed). Cairo, pp 888.

The Plant List (2016). Compositae. Royal Botanic Gardens, Kew. Retrieved 18 November 2016 from www.theplantlist.org

The Missouri Botanical Garden (2017). Compositae. Retrieved 14 July 2017 from www.tropicos.org

USDA (2018). Helenium amarum (Raf.) H. Rock var. amarum sneezeweed. https://plants.Usda.gov/core/profile?symbol=HEMA

Zareh MM (2005a). Synopsis of the family Asteraceae in Egypt. International Journal of Agriculture and Biology 5:832844.

Zareh M (2005b). Systematic and anatomical studies of Inuleae and Plucheeae in Egypt. Feddes Repertorium 116:43-53.
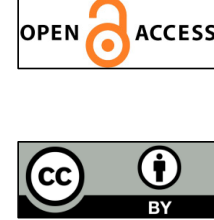

The journal offers free, immediate, and unrestricted access to peer-reviewed research and scholarly work, due SHST supports to increase the visibility, accessibility and reputation of the researchers, regardless of geography and their budgets. Users are allowed to read, download, copy, distribute, print, search, or link to the full texts of the articles, or use them for any other lawful purpose, without asking prior permission from the publisher or the author.

License - Articles published in Notulae Scientia Biologicae are Open-Access, distributed under the terms and conditions of the Creative Commons Attribution (CC BY 4.0) License.

(c) Articles by the authors; SHST, Cluj-Napoca, Romania. The journal allows the author(s) to hold the copyright/to retain publishing rights without restriction. 